\title{
DETERMINANTS OF ECO-INNOVATIONS - PRELIMINARY FINDINGS FROM SME SECTOR IN SILESIAN VOIVODESHIP
}

\author{
Małgorzata MARKOWSKA \\ Central Mining Institute; Katowice; mmarkowska@gig.eu; ORCID 0000-0002-9105-6856
}

\begin{abstract}
Purpose: The aim of the paper is to identify and assess the various factors - legal, technological or social, that determine the process of eco-innovation development in SMEs sector companies. Design/methodology/approach: The first part of this paper presents literature considerations on eco-innovation and its characteristics as well as types of determinants affecting its implementation. The occurrence and importance of particular determinants for the implementation of eco-innovation was then evaluated as a result of an own survey research carried out in 2020 on a sample of 96 SMEs implementing technologies for environmental protection from the Silesian Voivodeship.
\end{abstract}

Findings: The analysis and the obtained results indicate a significant positive influence of managerial environmental awareness, slightly less significant impact of final consumers and communication style in the company and significant impact of legal regulations, which may be a barrier for eco-innovation implementation.

Research limitations/implications: The results provide a basis for activities to improve the effectiveness of the implementation of eco-innovation in enterprises. Limitations of the study include the subjectivity of respondents' opinions and the relatively small research sample, which may limit the generalization of the results.

Practical implications: The results provide a basis for activities to improve the effectiveness of the implementation of eco-innovation in enterprises. Limitations of the study include the subjectivity of respondents' opinions and the relatively small research sample, which may limit the generalization of the results.

Originality/value: The contribution of the research to the development of management sciences mainly includes the formulation and empirical verification of a set of key factors determining the process of eco-innovation implementation in SMEs in post-industrial region.

Keywords: eco-innovation, determinants of eco-innovation, small and medium-sized enterprises (SMEs), Silesian Voivodeship.

Category of the paper: research paper.

JEL Classification: O31, O32, Q55. 


\section{Introduction}

Modern companies operating on the market strive to obtain competitive advantage, reduce costs, increase efficiency and environmental solutions, while meeting customer expectations. This task is particularly important for those companies for which the impact on the environment is not indifferent. Economic development should proceed in a sustainable manner, maintaining economic, social and environmental equilibrium. The implementation of modern environmental technologies is becoming an important challenge for modern economies. It is therefore necessary to take actions aimed at rational use of resources. Regarding the discussion about integrating in-novation and sustainability domains, one of the first studies published in the literature were carried out by C. Fussler and P. James (1996), and K. Rennings (1998, 2000). C. Fussler and P. James (1996) are credited as the authors of the term "eco-innovation" in a book titled "Driving Eco-Innovation: A Break-through Discipline for Innovation and Sustainability" (Pacheco et al., 2018).

Although the term eco-innovations became known in the late 90-ties, the eco-innovations are still relatively new category in economic and management sciences. The implementation and management of eco-innovation has been widely discussed in the context of large companies, mainly in the industrial and technology sectors. However, the discussion on the impact in small and medium enterprises (SMEs) is still very inconclusive.

Therefore, the importance of this study is to broaden the understanding of the determinants of eco-innovation in SMEs, aiming to provide a more comprehensive understanding of the reality of small businesses. An appropriate strategy to better understand this phenomenon and landscape is to analyze what are the determinants of eco-innovation in Silesian SMEs and whether or not they are similar to the empirical results available in the literature.

The paper presents the results of own research conducted in 2020 in the Silesian Voivodeship. The key factors determining the generation of eco-innovation were identified on the basis of the literature review and the own questionnaire was elaborated to measure the importance these determinants in Silesian SMEs. In the first phase of the research, the enterprises were selected purposively - they had to belong to the SME sector, run their business in the Silesian Voivodeship and their activities should be related to environmental technologies. Then random selection was applied. As a result a total of 96 complete questionnaires were obtained.

The structure of the paper is as follows. First, the literature is reviewed and the definition and the determinants of eco-innovation is described. Then, the methodology is described. The research findings are delivered in section 4. The paper ends with the discussion and conclusions. 


\section{Theoretical background and literature review}

\subsection{The concept and types of eco-innovation}

The paradigm of sustainable socio-economic development balanced in terms of its impact on the natural environment began to gain importance in the 1990s. Dynamic changes taking place in the modern world, including the growing ecological burden associated with the depletion of natural re-sources and generation of excessive amounts of pollution, the need to respect increasingly stringent environmental norms and standards, as well as growing environmental awareness of consumers resulted in the need for companies to find new sources of competitive advantage (Wagner, 2009). Key in this context is the development of innovation potential (Pichlak, 2012), understood as the ability and willingness of the organization to generate and implement innovation (Poznańska, 1998). At the same time, it has become more and more common to distinguish the so-called eco-innovation among all innovation activities.

Despite the fact that eco-innovations became the subject of research al-ready in the 1970s, and the term eco-innovations became common in the late 1990s (Bałazińska et al., 2020), the eco-innovations are still relatively new category in economic and management sciences and due to the large scope of their meanings, ecological innovations can be interpreted very broadly. Therefore there are many definitions and use of different concepts and terminology for this phenomenon, including among others eco-innovation, ecological innovation, environmental innovation, green innovation, sustainable innovation, etc. (Fussler, James, 1996; Rennings, 2000; PARP, 2008; Ekins, 2010; Miedzinski, Charter, O'Brien, 2013). Although, only the name of eco-innovation is used in this paper.

The following table summarizes selected definitions of eco-innovation, that allow a better understanding of the variants and evolution of the concept (Table 1).

Table 1.

Selected definitions of eco-innovations

\begin{tabular}{|l|l|}
\hline \multicolumn{1}{|c|}{ Definition } & \multicolumn{1}{|c|}{ Authors } \\
\hline $\begin{array}{l}\text { Eco-innovation is the process of developing new products, processes or } \\
\text { services which provide customer and business value but significantly decrease } \\
\text { environmental impact" }\end{array}$ & C. Fussler, P. James (1996) \\
\hline $\begin{array}{l}\text { Intentional conduct characterized by initiative, comprising the stage of } \\
\text { product design and integrated management during its life cycle, which } \\
\text { subsequently contributes to pro-ecological modernization of the industrial } \\
\text { era's societies, by accounting for environmental issues in the development of } \\
\text { products and related processes. Eco-innovations lead to integrated solutions }\end{array}$ & \\
$\begin{array}{l}\text { aimed at reducing the expenditure of resources and energy, while } \\
\text { simultaneously improving the quality of products and services. Technological } \\
\text { innovation is one of the ways of pursuing eco-innovation }\end{array}$ & \\
\hline $\begin{array}{l}\text { New products and processes that provide customer value, while using fewer } \\
\text { resources and resulting in reduced environmental impacts }\end{array}$ & $\begin{array}{l}\text { G. Johansson, T. Magnusson } \\
\text { (1998) } \\
\text { OECD (2009) }\end{array}$ \\
\hline
\end{tabular}


Cont. table 1.

\begin{tabular}{|c|c|}
\hline $\begin{array}{l}\text { New or modified processes, techniques, practices, systems and products } \\
\text { aimed at preventing or reducing environmentally negative impacts or } \\
\text { environmental damage }\end{array}$ & $\begin{array}{l}\text { K. Rennings (2000) } \\
\text { J. Horbach (2008) } \\
\text { T.J. Foxon, P. Pearson (2008) } \\
\text { J. Horbach, C. Rammer, } \\
\text { K. Rennings (2012) }\end{array}$ \\
\hline $\begin{array}{l}\text { "Eco-innovation is any form of innovation aiming at significant and } \\
\text { demonstrable progress towards the goal of sustainable development, through } \\
\text { reducing impacts on the environment or achieving a more efficient and } \\
\text { responsible use of natural resources, including energy" }\end{array}$ & European Commission (2007) \\
\hline $\begin{array}{l}\text { "...any innovation, implemented in accordance with the applicable law, } \\
\text { which benefits the natural environment, in particular through minimizing } \\
\text { consumption of natural resources per produced product unit, as well as } \\
\text { minimizing the emission of hazardous substances into the environment during } \\
\text { production, use and after use of the product" }\end{array}$ & PARP (2008) \\
\hline $\begin{array}{l}\text { "Eco-innovation is the production, application or exploitation of a good, } \\
\text { service, production process, organizational structure, or management or } \\
\text { business method that is novel to the firm or user and which results, throughout } \\
\text { its life cycle, in a reduction of environmental risk, pollution and the negative } \\
\text { impacts of resource use (including energy use) compared to relevant } \\
\text { alternatives" }\end{array}$ & $\begin{array}{l}\text { R. Kemp, P. Pearson (2008), } \\
\text { OECD (2009) }\end{array}$ \\
\hline $\begin{array}{l}\text { "[eco-innovation is] } \ldots \text { innovation that improves environmental } \\
\text { performance." }\end{array}$ & $\begin{array}{l}\text { J. Carrillo-Hermosilla, } \\
\text { P. del Rio, T Konnola (2010) }\end{array}$ \\
\hline $\begin{array}{l}\text { "Eco-innovation is an innovation that improves both economic and } \\
\text { environmental performance" }\end{array}$ & $\begin{array}{l}\text { G. Huppes et. al. (2008) } \\
\text { P. Ekins (2010) }\end{array}$ \\
\hline $\begin{array}{l}\text { "Eco-innovation is any innovation that reduces the use of natural resources } \\
\text { and decreases the release of harmful substances across the whole life-cycle" }\end{array}$ & $\begin{array}{l}\text { Eco - innovation Observatory } \\
\text { EIO } 2011\end{array}$ \\
\hline $\begin{array}{l}\text { "Eco-innovation is any innovation that makes progress towards the goal of } \\
\text { sustainable development by reducing impacts on the environment, increasing } \\
\text { resilience to environmental pressures or using natural resources more } \\
\text { efficiently and responsibly" }\end{array}$ & European Commission (2011) \\
\hline
\end{tabular}

Source: own study based on: Fussler and James, 1996; Carley and Spapens, 2000, p. 157; Rennings, 2000; EC, 2007; Foxon, Pearson, 2008; Horbach, 2008; Huppes et. al., 2008; Ekins, 2010; EC, 2011, p. 3; EIO, 2011; Horbach, Rammer Rennings, 2012; Pacheco et.al., 2017; Woźniak, Woźniak, 2021.

Although official definitions from EU documents can be found in the table above, even the European Economic and Social Committee, which evaluated the provisions of the Eco-action Plan (Eco-AP), pointed to some difficulties in establishing a universal, widely accepted definition of eco-innovation (Opinion..., 2012).

Based on the most generally accepted definition, eco-innovations are new or significantly im-proved solutions (products, management methods, manufacturing methods, ways of service provision and processes of resource exploitation) which ensure lower risk of environmental pollution, use fewer raw materials and release fewer pollutants than alternative solutions, so reduce negative impact on the natural environment or contribute to the protection of the environment, while delivering value to consumers and business (Cooke, 2011), as the concept of eco-innovation emphasizes the integration of environmental management into the economic process (Karakaya, Hidalgo, Nuur, 2014).

Eco-innovations may be systematized taking into account various criteria. For this reason, as in the case of innovations, these divisions are mostly not precise, as the same eco-innovation may be classified in several groups. Most often, eco-innovations may be of the following nature: 
process, product, organizational or marketing. At the same time, eco-innovation is not limited to innovation in products, processes, marketing methods and organizational methods, but the scope of eco-innovation may go beyond the conventional organizational boundaries of the innovating organization and involve broader social arrangements that trigger changes in existing socio-cultural norms and institutional structures (OECD, 2009; Machiba, 2010).

The following table (Table 2) summarizes selected types of eco-innovations and their explanations and examples.

Table 2.

Examples of specific types of eco-innovation

\begin{tabular}{|c|c|}
\hline $\begin{array}{c}\text { Type of eco- } \\
\text { innovation } \\
\end{array}$ & Understanding and examples \\
\hline $\begin{array}{l}\text { Product eco- } \\
\text { innovation }\end{array}$ & $\begin{array}{l}\text { - launching on the market a product or service that is new or significantly } \\
\text { improved in terms of its features or uses, } \\
\text { - producing goods in a manner that leads to decreased environmental impacts and } \\
\text { less resource use during operation, e.g. due to eco-design, } \\
\text { - replacing inputs with materials of improved characteristics (breathable textiles, } \\
\text { lightweight but resistant composites, environmentally friendly plastics, etc.), } \\
\text { - products with significantly reduced energy consumption (energy efficient } \\
\text { refrigerators, etc.), } \\
\text { green financial products (e.g. eco-leases), environmental services (e.g. waste } \\
\text { management) and less resource intensive services (e.g. car sharing). }\end{array}$ \\
\hline Process eco-innovation & $\begin{array}{l}\text { - implementation of new or significantly improved production or supply methods, } \\
\text { which reduce material consumption and risks as well as resulting in cost savings, } \\
\text { - substitution of harmful inputs during production (e.g. replacing toxic } \\
\text { substances), } \\
\text { - optimization of the production process (e.g. improving energy or resource } \\
\text { efficiency), }\end{array}$ \\
\hline $\begin{array}{l}\text { Organizational eco- } \\
\text { innovation }\end{array}$ & $\begin{array}{l}\text { - introduction of organizational methods and management systems for dealing } \\
\text { with environmental issues in production and products (e.g. pollution prevention } \\
\text { schemes, environmental management and auditing systems, chain } \\
\text { management), } \\
\text { various collaborative organizational forms and their potential eco-innovative } \\
\text { qualities (e.g. business networks and clusters, advanced solutions in industrial } \\
\text { symbiosis). }\end{array}$ \\
\hline $\begin{array}{l}\text { Marketing eco- } \\
\text { innovation }\end{array}$ & $\begin{array}{l}\text { - introduction of new marketing methods or techniques, which lead to changes in } \\
\text { product design or packaging, product placement, product promotion or pricing } \\
\text { with particular regard to environmental principles or the shaping of ecological } \\
\text { awareness as part of promotion (e.g. eco-labelling), } \\
\text { - introduction of green branding for better commercialization of products or } \\
\text { services. }\end{array}$ \\
\hline Social eco-innovation & $\begin{array}{l}\text { market-based dimensions of behavioral and lifestyle change and the ensuing } \\
\text { demand for green goods and services, } \\
\text { - user-led innovation, meaning that the functionality of new goods is developed } \\
\text { with stakeholders, thereby minimizing the risk of superfluous product features, } \\
\text { - product sharing, which may lead to an absolute decrease of material use without } \\
\text { diminishing the quality of the services they provide to users, } \\
\text { - innovative social concepts (e.g. green living). }\end{array}$ \\
\hline
\end{tabular}


Cont. table 2.

\begin{tabular}{|c|c|}
\hline System eco-innovation & $\begin{array}{l}\text { - aiming to improving the efficiency of the whole system rather than focusing on } \\
\text { the individual components used in systems, ranging from "complex products" } \\
\text { (e.g. houses) to entire production and consumption systems (e.g. cities), } \\
\text { - collection of changes implemented by design (e.g. system eco-innovation } \\
\text { related to a house is not just about insulating windows or using a better heating } \\
\text { system, but about innovating the overall design to improve its functionality), } \\
\text { set of interconnected innovations that improve or create entirely new systems } \\
\text { delivering specific functions with reduced overall environmental impact, } \\
\text { e.g. shared-bike systems (and related infrastructure such as bike stations), } \\
\text { as well as reduction of the need for travel (requiring that supermarkets, daycare } \\
\text { facilities, etc., are incorporated into new housing developments). }\end{array}$ \\
\hline
\end{tabular}

Source: own study based on: Rennings, 1998; Charter, Clark, 2007; Kemp, Pearson, 2008; Wagner, 2008.

\subsection{Determinants of eco-innovations}

An organization's ability to generate and implement innovation, including eco-innovation, is the result of the existence and impact of various factors that determine its (eco)innovativeness. The determinants of the processes of implementation and generation of eco-innovation are very diverse and multifaceted, and include both determinants that can be opportunities and others that are barriers or threats to the development of eco-innovation.

To identify the main factors stimulating and limiting the generation of eco-innovation, the existing divisions and classifications of these factors in the literature were analyzed. A significant number of authors divide the factors determining the generation of eco-innovation into external (exogenous), whose source lies in the environment of the organization, and internal (endogenous), depending on its internal specificity (del Río, 2009; Araszkiewicz, 2012; del Río, Peñasco, Romero-Jordán, 2016). Some authors complement the classification by including international factors (Hrabynskyi, Horin, Ukrayinets, 2017) or factors resulting from the characteristics of the eco-innovation itself (Araszkiewicz, 2012). O.E. Hansen et al. (2002) state that the eco-innovation capability of SMEs is a result of the interplay between competencies, network relationships and the strategic orientation of the firm, indicating that policies to support the adoption of eco-innovation by SMEs must take an integrated form.

According to J. Horbach (2008), the factors determining eco-innovativeness form three main groups: demand factors, supply factors and external factors related to public institutions regulation. A. Reid and M. Miedziński (2008) adapt J. Horbach's approach by adding the tax policy, which can affect the prices of eco-innovative goods and services by shaping their market. The Polish Agency for Enterprise Development indicates four main groups factors affecting the rate of implementation of eco-innovations (PARP, 2015): (i) supply factors related to technological trends (e.g. CP, CSR), (ii) demand factors - related to consumer preferences in terms of environmentally-friendly production methods or products (greens consumers), (iii) regulatory environment (legislation), (iv) company-specific factors - related to industry, company size, environmental policy, financial strength, market share. 
It is noticeable that in the literature the division and classification of determinants of eco-innovation are very diverse, and many authors do not categorize or group the factors, but only list and describe those that are important for the innovativeness of the company, depending on the direction of the analysis and regional conditions.

For example, as a result of investigating the barriers and driving aspects for eco-innovation in German SMEs that participate in an innovation network called Ecoprofit, J. Klewitz, A. Zeyen and E.G. Hansen (2012) find that the main drivers of eco-innovation are (i) cost efficiency, proactive contact through external initiatives and the desire for continuous improvement; (ii) cost, cost reduction and risk management (avoiding negative environmental impacts and legislation compliance); (iii) improving energy efficiency, becoming more attractive to employees (creating a shared company culture), reputation and brand image, and profit and sales (putting pressure on suppliers to meet sustainable standards). As highlighted by J. Zarębska and M. Michalska (2016) and J. Przychodzeń (2019) an important factor influencing the implementation rate and type of eco-innovations is also the increase in environmental awareness of consumers and stakeholders, the dissemination of knowledge and access to modern technologies from external sources and globalization processes with particular emphasis on the development of multinational corporations and the resulting increase in interest in environmental management tools and strategies, such as implemented environmental management standards (EMAS, ISO 14000), strategies of CP (Clean Production) and CSR (Corporate Social Responsibility), eco-design or eco-labeling.

Generally, the analysis of the literature shows that the determinants of eco-innovation include among others: public policy (Ghisetti, Pontoni, 2015; del Rio et al., 2016), associated with legal provisions and regulations (Cleff, Rennings, 1999; Hojnik, Ruzzier, 2016) and financial incentives (Kemp, Pearson, 2008); cost reduction, profit, social pressure (including customers' expectations) and the expected improvement of the company's image (Kemp, Pearson, 2008; Kammerer, 2009; Bossle et al., 2016), opportunities and changing conditions for cooperation (Rave, Goetzke, Larch, 2011; Horbach et al, 2012;) and internal capabilities (Horbach, 2008; del Rio et al., 2016) with some authors arguing that organizations implementing eco-innovations rely more on the support of business environment organizations, the results of public research organizations and institutions and the knowledge of suppliers, while organizations implementing non-environmental innovations - show much greater dependence on internal human capital (Belin, Horbach, Oltra, 2011).

The analysis of the literature shows that the main obstacle to the development of ecoinnovation is the economic factor (lack of own resources). Enterprises make little use of external sources such as credits, loans and EU funds, also because of the fact, that the process of applying for these funds itself causes some problems for entrepreneurs, which discourages them from applying for them (Wielewska, 2019). Low interest in the introduction of ecological innovations in Poland is also a result of lack of knowledge. It is most visible in the SME sector, 
as many of these companies have little capital, lack of experience in this field and small human resources (Zuzek, 2015).

The review of the literature and the results of existing research indicate the existence of many proposals of factors determining the eco-innovation generation process in SMEs. It is difficult to assess which of these factors are the most important in the development of ecoinnovations, as empirical research provides various points of view on this topic (Marczewska, 2016). Additionally, some of these approaches are fragmentary and focus on analyses narrowed to specific macroeconomic conditions, specific types of eco-innovations, cover only selected locations or chosen sectors, or even companies. Therefore, there is still a research gap in an approach aimed at identifying and assessing strategic factors determining the eco-innovation development by SMEs.

Within own research, based on the literature review, determinants of eco-innovations have been divided into 4 main groups (Table 3 ).

Table 3.

Determinants of eco-innovations

\begin{tabular}{|c|c|}
\hline Group of determinants & Aspects \\
\hline $\begin{array}{l}\text { Regulation and policy } \\
\text { determinants }\end{array}$ & $\begin{array}{l}\text { - Implementation and institutionalisation of environmental policy } \\
\text { instruments: economic and regulatory instruments } \\
\text { - Regulatory design: stringency, flexibility, time frame } \\
\text { - Anticipation of future environmental regulations }\end{array}$ \\
\hline Market (demand) factors & $\begin{array}{l}\text { - The intensity of competition and market position, impacts of competitors } \\
\text { strategies } \\
\text { - Impact of final consumers and users of products and services, especially } \\
\text { customers' ecological requirements } \\
\text { - Suppliers impact, including greening the suppliers and opportunities to work } \\
\text { with suppliers on early design and development of eco-innovative solutions }\end{array}$ \\
\hline $\begin{array}{l}\text { Technological factors - } \\
\text { proximity and availability } \\
\text { of technology outside the } \\
\text { company }\end{array}$ & $\begin{array}{l}\text { - Cooperation with universities and scientific institutes, technology parks and } \\
\text { business incubators or business environment institutions (BIOs) } \\
\text { - Access to state-of-the-art technologies as a result of participation in } \\
\text { cooperation networks } \\
\text { - Access to best knowledge from cooperation networks } \\
\text { - Access to advisory services, regardless of the source }\end{array}$ \\
\hline Internal context factors & $\begin{array}{l}\text { - Organizational resources, including key competencies } \\
\text { - Environmental Management Systems (EMS) } \\
\text { - Communication system within the organization (information flow, } \\
\text { opportunities for collaboration and mutual learning) } \\
\text { - Managerial environmental awareness (including environmental risk } \\
\text { awareness (ERA) and environmental cost-benefit awareness (ECA) }\end{array}$ \\
\hline
\end{tabular}

Source: own study, based on: Clef, Rennings, 1999; Rennings, Zwick, 2002; Horbach, 2008; Rave, Goetzke, Larch, 2011; Ghisetti, Pontoni, 2015; Zuzek, 2015; del Río, Peñasco, Romero-Jordán, 2016; Hojnik, Ruzzier, 2016, Hrabynskyi, Horin, Ukrayinets, 2017; Przychodzeń, 2019

The results of own research are presented in the further part of the paper. 


\section{Research methodology}

In order to determine the main determinants of eco-innovative activities of SMEs in Silesian Voivodeship, empirical research was conducted and its partial results are presented in this study. The research was carried out in the Silesian Voivodeship in the first half of 2020 using the questionnaire method.

A multidimensional questionnaire was developed on the basis of an in-depth analysis of the literature and own experience, which combines a tool to measure the factors that determine the generation of eco-innovation, the level of eco-innovation and organizational effectiveness. In order to measure the individual determinants of eco-innovation, consisting of the influence of each group of factors, a five-point attitude scale developed by R. Likert was used (from 1 no impact, to 5 - very strong impact).

Purposeful sampling was implemented, the selected companies had to belong to the SME sector, run their business in the Silesian Voivodeship and their activities should be related to environmental technologies. The adoption of the last condition resulted from author's experience within the Technologies for Environmental Protection Observatory operating within the framework of the Network of Regional Observatories (Bondaruk, Gieroszka, Kruczek, 2016). Then, random selection was applied. The questionnaire was addressed to owners, managers or persons responsible for environmental protection in the company.

A total of 96 complete questionnaires were obtained. The research covered 36 micro enterprises (37,5\%), 17 small companies $(17,7 \%)$ and 43 medium-sized enterprises $(44,8 \%)$.

The majority of surveyed companies (49\%) are active on the market at regional scale, $25 \%$ are active on a national scale, whereas $26 \%$ internationalize their activities. The sample included mainly service enterprises $(47 \%)$, less often operating in production sector $(26 \%)$ or trade $(6 \%)$. The rest of responders indicated multiple activities. The research sample included companies of different ages - companies with a business period less than 5 years $(22,9 \%)$, of 10-20 years $(29,2 \%)$, as well as mature entities with a market activity between 20-30 years $(33,3)$ or even longer than 30 years $(14,6 \%)$.

The empirical material from the surveyed enterprises was collected based on the judgments of the respondents.

The collected material was subjected to statistical analyses, which were performed using IBM SPSS Statistics 25.0. Basic descriptive statistics were calculated using the program along with the Shapiro-Wilk test of normality. To determine the relationship between quantitative variables, correlation analysis was performed using Pearson's r coefficient.

The purpose of this paper, however, is to focus only on those results that relate to the determinants of eco-innovation. These results are discussed and presented in the next chapter. 


\section{Research findings and discussion}

The research has confirmed that each innovation idea arises under different circumstances, so it is difficult to describe a single, precise approach to this issue. For this reason, respondents were sometimes unable to clearly identify if specific factor had a dominant influence, without indicating eco-innovation characteristics.

Nevertheless, according to the most respondents, the following groups of determinants have "strong impact" or "very strong impact" on the process of generating eco-innovations: managerial environmental awareness $(71,88 \%)$ and regulatory aspects (legal regulations) $(70,83 \%)$. The next most significant factors were impacts of final customers - indicated as having "strong impact" or "very strong impact" by $61,46 \%$ of respondents and internal communication system in the organization $(60,42 \%)$ (Figure 1$)$.

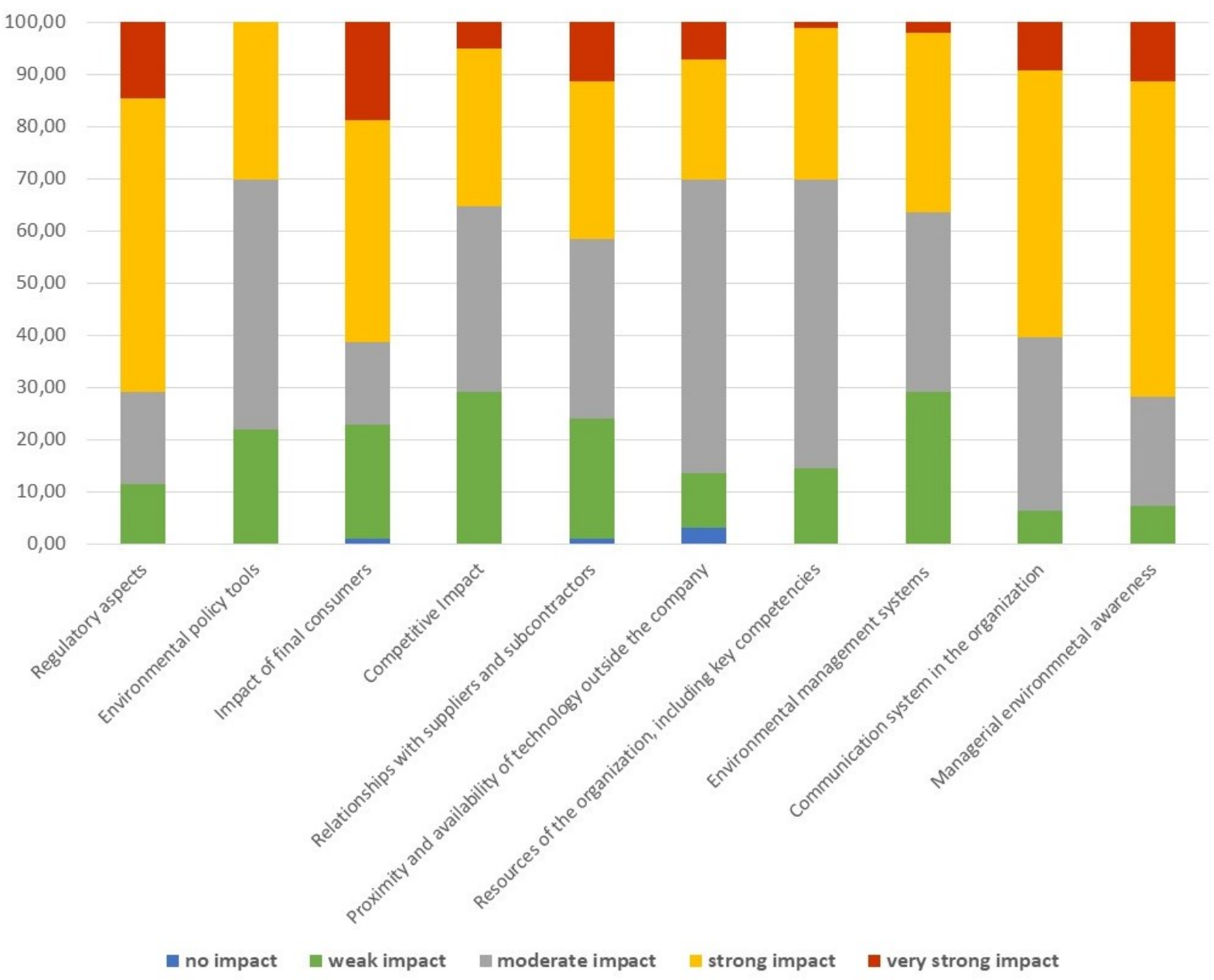

Figure 1. The strength of impact of particular groups of eco-innovations determinants. Source: own elaboration based on the results of the conducted survey.

What's important, regulatory aspects tend to be seen as barriers to enterprise growth and their eco-innovativeness, as $40,63 \%$ of respondents indicated that it was "difficult" or "very difficult" for their company to comply with national environmental regulations over the past 3 years. In the case of international environmental regulations, the value of this indication was 
only $21,87 \%$, while $47,92 \%$ of respondents felt that the requirements of international law are "neither easy nor difficult" to meet (Figure 2). This may be due to the fact that $70 \%$ of surveyed companies are active on the market at regional or national scale, which means that they have to deal mostly with national regulations on a daily basis. Additionally, $64,58 \%$ of respondents indicated, that "Existing national environmental regulations are very restrictive", whereas $65,63 \%$ of respondents "agree" or "strongly agree" that the frequent and significant changes in national environmental regulations impacting.

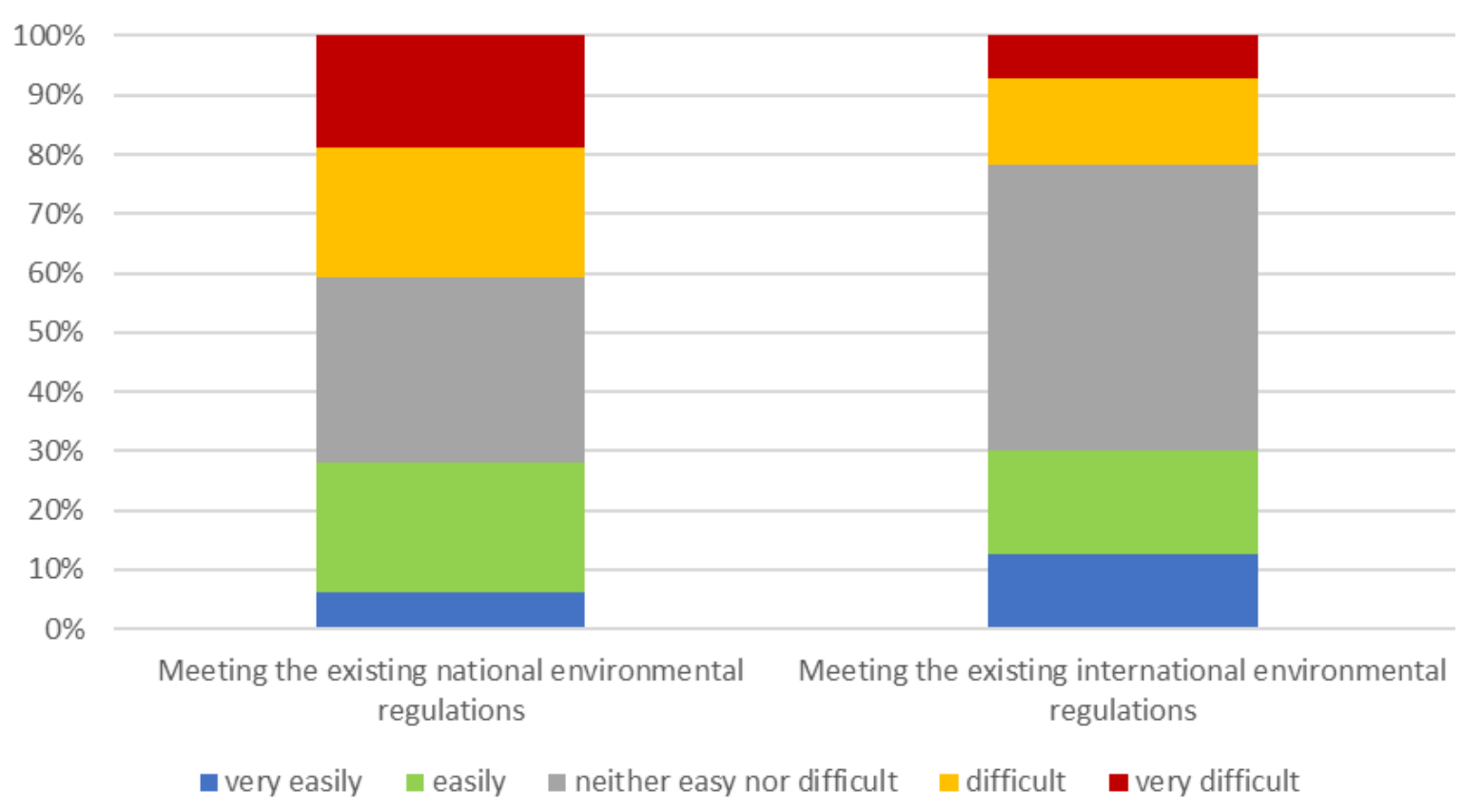

Figure 2. Challenge of meeting environmental regulations. Source: Own elaboration based on the results of the conducted survey.

As the problem of defining and evaluating the forces that positively and negatively affect the eco-innovation activities of companies is very important not only for individual companies but also for industry organizations, R\&D institutes and local and regional governments, the dominance of environmental regulations as a determinant of eco-innovation is consistent with the results of many theoretical and empirical studies carried out over many years and in different regions (Cleff, Rennings, 1999; Rennings, Zwick, 2002; Rave et al., 2011). Also the tentative negative impact of regulatory factors is in line with previous experiences described in literature, as legislation seems to be the most commonly experienced external barrier in some regions (Hojnik, Ruzzier, 2016; del Rio et al., 2016, Hrabynskyi et al., 2017).

At the same time, impact of the "environmental policy tools" has been found in Silesian Voivodeship as significantly less important than regulations (Figure 1). Although since the early 1970s, environmental policies have made a shift from end-of-pipe solutions to prevention and control, for many responders - financial incentives are still equated as the most important instruments. Therefore, responders have been asked, among others, about the importance of preferential taxes and subsidies. Less than $16 \%$ of responders agree that there are any 
preferential taxes for eco-innovations implementation, whereas less than $42 \%$ - notice the existence of subsidies. At the same time, almost $42 \%$ "agree" or "strongly agree" that the existing system of environmental taxes hampers the eco-innovation initiatives and their development (Figure 3).

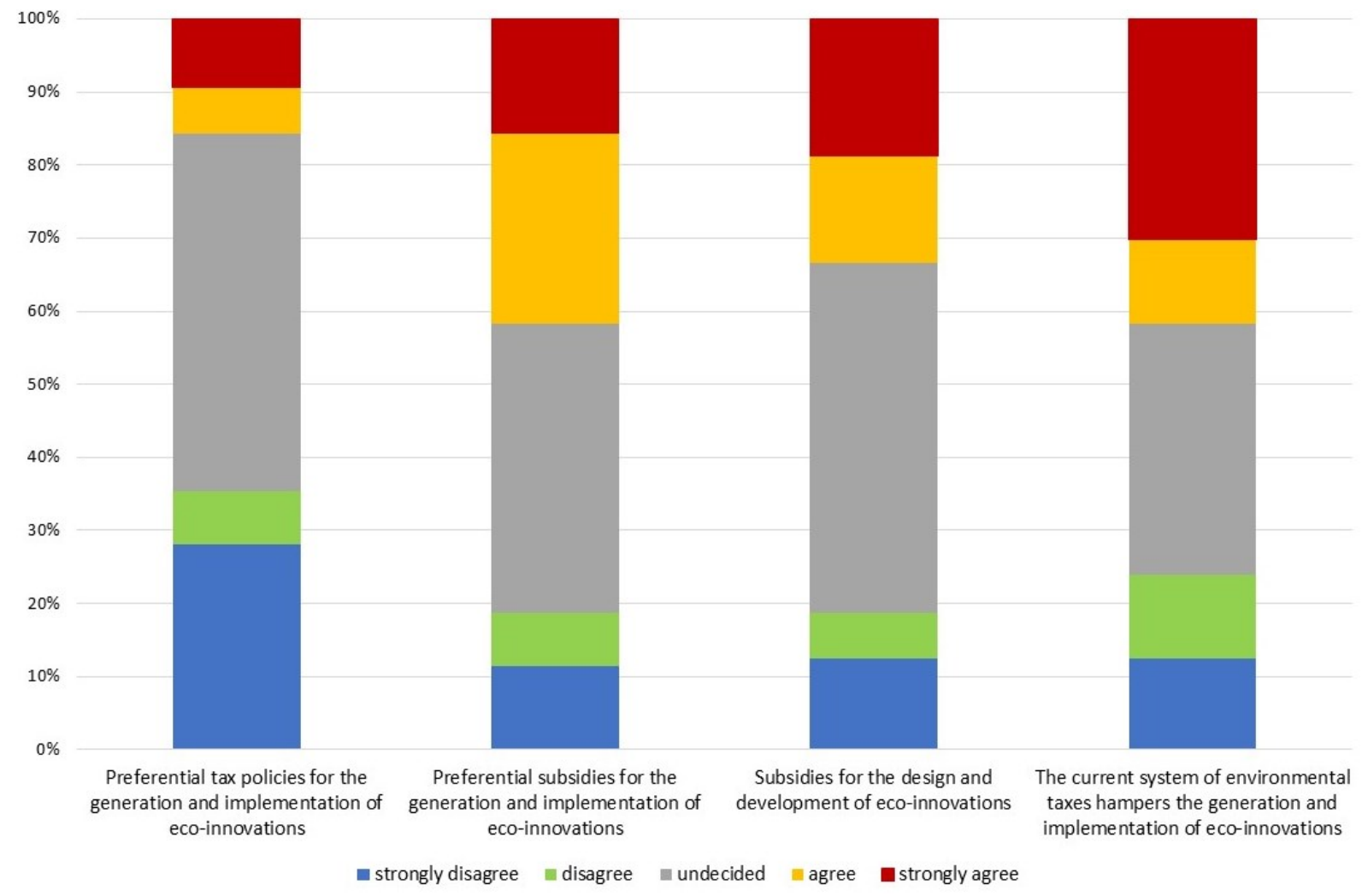

Figure 3. Existence of different aspects of environmental policy and their importance for eco-innovation development. Source: Own elaboration based on the results of the conducted survey.

The other important external driver, identified in many researches is a final customers pressure (Cleff, Rennings, 1999; Rave et al., 2011; Pichlak, 2012; Hojnik, Ruzzier, 2016; Hrabynskyi et al., 2017). Among the conditions of this determinant is the increase in environmental awareness of consumers, translating into preferences for environmentally friendly products, which can be interpreted as an environmentally oriented demand effect. Although M. Koszewska's (2015) findings show that consumers on the Polish market have trouble finding and distinguishing ecological products from conventional ones, $72,92 \%$ of respondents of this survey "strongly agree" or "rather agree" with the sentence that "An organization's compliance with environmental requirements is an important issue for its customers". At the same time, only 58,33\% of respondent indicate, that "Environmental requirements of customers stimulate efforts within the organization", which is in line with overall calculation of strength of this determinant, as shown on Figure 4. 


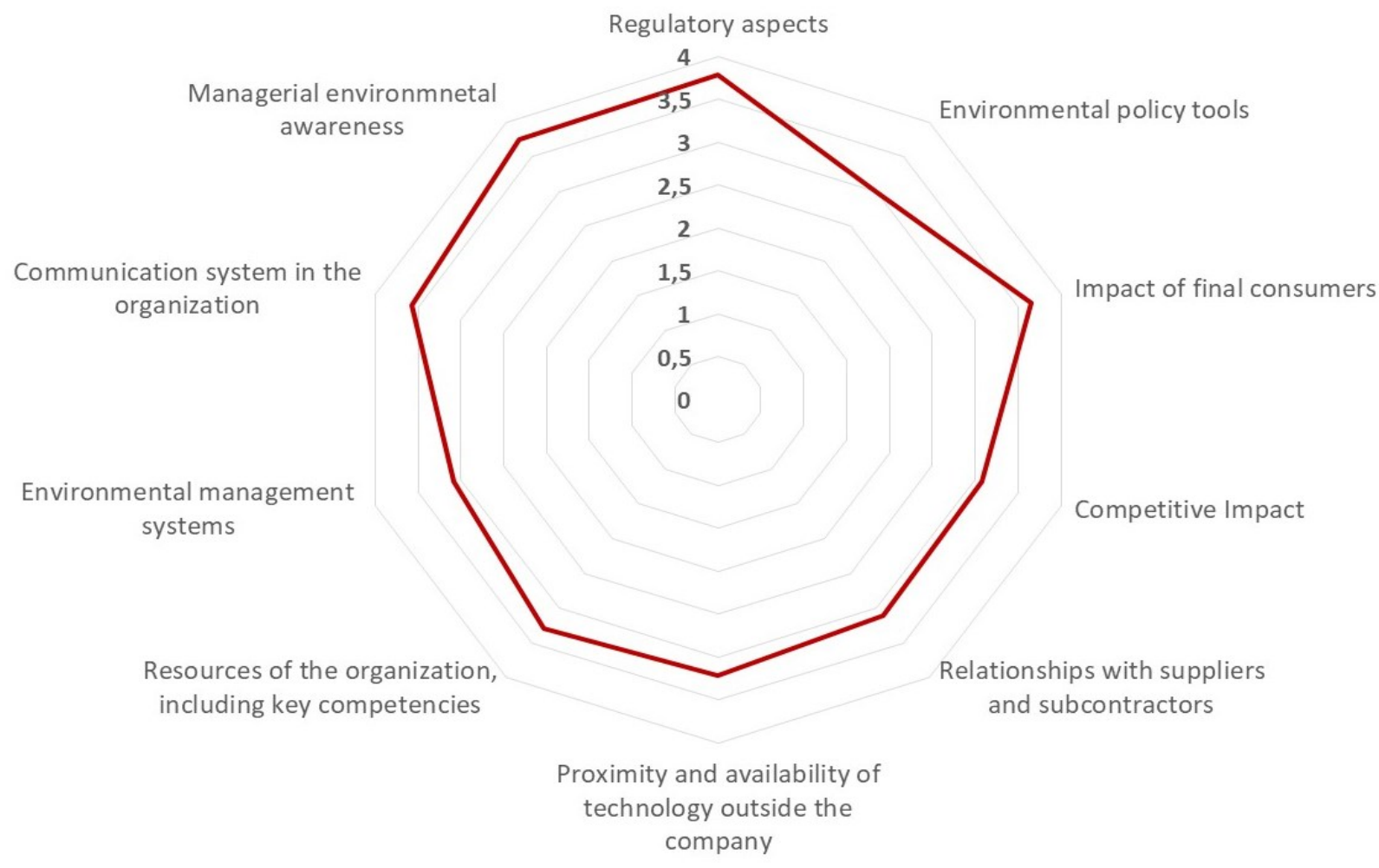

Figure 4. Determinants of eco-innovation implementation - mean results on Likert scale. Source: own elaboration based on the results of the conducted survey.

Managerial environmental awareness is an internal driver, which plays a crucial role in taking business decisions in more sustainable way. Following D. Gadenne, J. Kennedy and C. McKeiver (2009) and X. Peng and Y. Liu (2016), managerial environmental awareness has been divided into environmental risk awareness (ERA) and environmental cost-benefit awareness (ECA). Within the research carried out in Silesian Voivodeship, items related with ERA have ben indicated as having "strong impact" or "very strong impact" on the process of generating eco-innovations by $79,17 \%$ of respondents, whereas items related with ECA by $59,37 \%$, which indicates that this type of environmental awareness was dominant among the respondents. Executives with a dominant environmental risk awareness (ERA) are driven by environmental ethics and moral considerations - they pay much more attention to the negative effects their company has on the environment and the environmental problems in the industry. They are also more knowledgeable about how environmental laws and regulations affect the company and what "environmental best practices" exist in the industry. Therefore, executives with a higher ERA are more likely to focus on eco-innovations with higher environmental performance, and therefore are more likely to implement process and product eco-innovations (improving existing products or introducing new products) to reduce their environmental impact (Peng, Liu, 2016). In contrast, dominant environmental cost-benefit awareness (ECA) refers to managers' understanding of the potential savings and/or increased profits to the organization from implementing better environmental and pollution prevention practices, reflecting profit motivation. Managers with higher ECA thus prefer environmental innovations with higher efficiency and lower investment. 


\section{Conclusions}

The research has confirmed that each innovation idea arises under different circumstances, so it is difficult to describe a single, precise approach to this issue. Therefore, in order to determine the main determinants of eco-innovative activities of companies in the SME sector, empirical research was conducted, the results of which are partially presented in this study. The results of author's survey shows that the main factors influencing the adoption of ecoinnovation activities are regulatory aspects (legal regulations), managerial environmental awareness, impacts of final customers as well as communication style and system in the company. In general, most of these findings are in line with key determinants of eco-innovations identified by many authors in earlier studies. At the same time, as some of the earlier approaches are fragmentary and focus on analyses narrowed to specific macroeconomic conditions, specific types of eco-innovations, cover only selected locations or chosen sectors, or even companies, the contribution of the research to the development of management sciences mainly includes the formulation and empirical verification of a set of key factors determining the process of eco-innovation implementation in SMEs in Silesian Voivodeship reality, whose post-industrial character of the region, including especially the existence of significant negative externalities of the heavy industry influence on the intensive development of technologies for environmental protection.

The factors influencing the decision by Silesian companies to implement eco-innovations are: legal regulations concerning the environment, applicable taxes, fees and penalties associated with environmental pollution, need to meet requirements for contracts in public procurement desire to reduce high costs of energy, water and materials, current or expected market demand for eco-innovations. Also the importance of managerial environmental awareness as an crucial internal driver was confirmed.

The result of the research showed also that small and medium-sized enterprises, despite their willingness to introduce pro-environmental innovations, encounter a number of barriers preventing their development in this respect. The most important of them include: lack of financial resources for this type of solutions, frequent changes in the law and unclear environmental regulations.

An innovative contribution of the obtained research results to the development of management sciences is the identification and assessment of strategic factors determining the implementation of eco-innovations in the conditions of the Silesian Voivodship, whose postindustrial character of the region, including especially the existence of significant negative externalities of the heavy industry influence on the intensive development of technologies for environmental protection. The need for the development of environmental technologies and process and organizational eco-innovations is reflected in the development documents of the Silesian Voivodeship, which identify technological areas that form the basis of regional specialization (PRT Implementation Model, 2015) and in the conducted strategic activities of 
the Voivodeship for the development of the innovation ecosystem. In this context, relatively low ratio of determinants related to the importance of proximity and availability of technology outside the company and opportunities for knowledge exchange (indicated as having "strong impact" or "very strong impact" on the process of generating eco-innovations by only $30,21 \%$ of responders) clearly suggests the need to increase the awareness of entrepreneurs on existing opportunities for knowledge exchange, improve the effectiveness of existing networks and regional Research and Innovation Infrastructure performance and business use. These conclusions confirm the findings from the report "Improving the efficiency of research and innovation infrastructure in the Silesia Voivodeship -from divided to integrated and sustainable cooperation" (Kruczek et al., 2020). This is particularly important as opportunity for local cooperation for eco-innovation translation into reduced uncertainty in the implementation of eco-innovation. In this context, networking with other companies and institutions is particularly important. The main forms of support from the institutional environment in Silesian Voivodeship include among others: consulting, business incubators, technology parks. However, despite the observed increase in the number of these centers, the support that companies can count on is still insufficient. It is an even more important factor, because the lack of knowledge, previous innovative experience and accessibility to modern technologies, combined with relatively small capital at the disposal of SMEs, translates into a low interest in introducing ecological innovations in Poland, being still far below the European average (Woźniak, Woźniak, 2020).

\section{Acknowledgments}

Presented results have been developed as part of the project Network of Regional Specialised Observatories in the Entrepreneurial Discovering Process in the Silesian Voivodeship (SO RIS in PPO - II) implemented under the Regional Operational Programme of the Silesian Voivodeship for the years 2014-2020 (UDA-RPSL.01.04.01-24-06C8/19-00).

\section{References}

1. Araszkiewicz, K. (2012). Innowacje ekologiczne, a konkurencyjność gospodarki regionurozprawa doktorska. Wydział Zarządzania Uniwersytetu Ekonomicznego w Poznaniu.

2. Bałazińska, M., Markowska, M., Blaut, A., \& Głodniok, M. (2020). Life Cycle Assessment of Eco-Innovative Organo-Mineral Granulated Fertilizer's Production Technology, Rocznik Ochrona Środowiska, 22, 561-588. 
3. Belin, J., Horbach, J., \& Oltra, V. (2011). Determinants and Specificities of Ecoinnovations - An Econometric Analysis for the French and German Industry Based on the Community Innovation Survey. Cahiers du GREThA 2011-17. Groupe de Recherche en Economie Théorique et Appliquée.

4. Bondaruk, J., Gieroszka, A., \& Kruczek, M. (2016). Role of specialist observatories in regional innovative development. Problemy Eksploatacji, no. 4, 177-186.

5. Bossle, M., Dutra, B., De Barcellos, M., Vieira, L.M., \& Sauvée, L. (2016). The Drivers for Adoption of Eco-Innovation. Journal of Cleaner Production, vol. 113, 861-872.

6. Carley, M., \& Spapens, P. (2000). Dzielenie się światem. Zrównoważony sposób życia i globalnie sprawiedliwy dostęp do zasobów naturalnych $w$ XXI w. Białystok-Warszawa: Instytut na rzecz Ekorozwoju.

7. Carrillo-Hermosilla, J., del Rio, P., \& Konnola, T. (2010). Diversity of eco-innovations: reflections from selected case studies. Journal of Cleaner Production. Vol 18(10-11), 10731083.

8. Charter, M., \& Clark, T. (2007). Sustainable Innovation: Key conclusions from sustainable innovation conferences 2003-2006 organised by The Centre for Sustainable Design, Centre for Sustainable Design. Farnham, https://cfsd.org.uk/Sustainable\%20Innovation/ Sustainable_Innovation_report.pdf, 19.12.2018.

9. Cleff, T., \& Rennings, K. (1999). Determinants of environmental product and process innovation. Environmental Policy and Governance, 9(5), 191-201.

10. Cooke, P. (2011). Transition regions: Regional-national eco-innovation systems and strategies. Progress in Planning, vol. 76, no 3, 105-146.

11. del Río, P. (2009). The empirical analysis of the determinants for environmental technological change: a research agenda. Ecological Economics, vol. 68, 861-878.

12. del Río, P., Peñasco, C., \& Romero-Jordán, D. (2016). What drives eco-innovators? A critical review of the empirical literature based on econometric methods. Journal of Cleaner Production, vol. 112, 2158-2170.

13. Ekins, P. (2010). Eco-innovation for environmental sustainability: Concepts, progress and policies, International Economics and Economic Policy, vol. 7, no. 2, 267-290.

14. European Commission (2007). Competitiveness and Innovation Framework Programme (2007 to 2013). Brussels.

15. European Commission (2011). Innovation for a sustainable Future - The Eco-innovation Action Plan (Eco-AP). Brussels, COM (2011) 899 final, 2.

16. Foxon, T.J., \& Pearson, P. (2008). Overcoming barriers to innovation and diffusion of cleaner technologies: some features of a sustainable innovation policy regime. Journal of Cleaner Production. 16(1), 148-161.

17. Fussler, C., \& James, P. (1996). Driving Eco-innovation: A Breakthrough Discipline for Innovation and Sustainability. London, UK: Pitman Publishing. 
18. Gadenne, D.L., Kennedy, J., \& McKeiver, C. (2009). An empirical study of environmental awareness and practices in SMEs. Journal of Business Ethics, vol. 84(1), 45-63.

19. Ghisetti, C., \& Pontoni, F. (2015). Investigating policy and R\&D effects on environmental innovation: A meta-analysis. Ecological Economics, vol. 118, 57-66.

20. Hansen, O.E., Sondergard, B., \& Meredith, S. (2002). Environmental innovations in small and medium sized enterprises. Technology Analysis \& Strategic Management, 14(1), $37-56$.

21. Hojnik, J., \& Ruzzier, M. (2016). What drives eco-innovation? A review of an emerging literature. Environmental Innovation and Societal Transitions, vol. 19, 31-41.

22. Horbach, J. (2008). Determinants of environmental innovation - new evidence from German panel data sources. Research Policy, 37(1), 163-173.

23. Horbach, J., Rammer, C., \& Rennings, K. (2012). Determinants of eco-innovations by type of environmental impact - the role of regulatory push/pull, technology push and market pull. Ecological Economics, 78, 112-122.

24. Hrabynskyi, I., Horin, N., \& Ukrayinets, L. (2017). Barriers and drivers to eco-innovation: Comparative analysis of Germany, Poland and Ukraine. Economic and Managerial Spectrum, vol. 11, iss. 1, 13-24.

25. Huppes, G, Kleijn, R, Huele, R, Ekins, P, Shaw, B, Esders, M, \& Schaltegger, S. (2008). Measuring eco-innovation: framework and typology of indicators based on causal chains. Final Report of the ECODRIVE Project, CML, University of Leiden.

26. Johansson, G., \& Magnusson, T. (1998). Eco-innovations: a novel phenomenon? Journal of Sustainable Product Design, 7, 7-18.

27. Karakaya, E., Hidalgo, A., \& Nuur, C. (2014). Diffusion of eco-innovations: a review. Renewable and Sustainable Energy Reviews, 33, 392-399.

28. Kemp, R., \& Pearson, P. (2008). Final report MEI project about measuring ecoinnovation. Maastricht, www.merit.unu.edu/MEI2008.

29. Klewitz, J., Zeyen, A., Hansen, E.G. (2012). Intermediaries driving eco-innovation in SMEs: a qualitative investigation. European Journal of Innovation Management, Vol. 15, Iss. 4, 442-467.

30. Kruczek, M., Deska, M., Jąderko-Skubis, K., Markowska, M., Siodłak, Ł., Uszok, E., Zawadzki, P., Zawartka, P. (2020). Improving the efficiency of research and innovation infrastructure in the Silesia Voivodeship - from divided to integrated and sustainable cooperation. Katowice: Marshal's Office of the Silesian Voivodeship.

31. Machiba, T. (2010). Eco-innovation for enabling resource efficiency and green growth: Development of an analytical framework and preliminary analysis of industry and policy practices. International Economics and Economic Policy, vol. 7, no. 2, 357-370.

32. Marczewska, M. (2016). Factors Determining the Development of Product EcoInnovations. The Evidence from Poland. Studia i Materiaty, Wydziat Zarzadzania. Uniwersytet Warszawski, no. 2, vol. 2, 7-22. 
33. Miedzinski, M., Charter, M., \& O’Brien, M. (eds.) (2013). Eco-innovate! A guide to ecoinnovation for SMEs and business coaches, Eco-Innovation Observatory (EIO).

34. Opinion of the European Economic and Social Committee on the 'Communication from the Commission to the European Parliament, the Council, the European Economic and Social Committee and the Committee of the Regions: Innovation for a Sustainable Future - The Eco-innovation Action Plan (Eco-AP)' COM(2011) 899 final, 2012/C 351/14, source: $\quad$ https://eur-lex.europa.eu/legal-content/EN/TXT/?uri=OJ:C:2012:351:TOC, 12.04.2021.

35. Organization for Economic Co-operation and Development (OECD) (2009). Sustainable manufacturing and eco-innovation. Framework, practices and measurement. Synthesis report. Paris.

36. Pacheco, D.A.D.J., ten Caten, C.S., Jung, C.F., Ribeiro, J.L.D., Navas, H.V.G., \& CruzMachado, V.A. (2018). Eco-innovation determinants in manufacturing SMEs from emerging markets: Systematic literature review and challenges. Journal of Engineering and Technology Management, 48, 44-63.

37. Peng, X., \& Liu, Y. (2016). Behind eco-innovation: Managerial environmental awareness and external resource acquisition. Journal of Cleaner Production, vol. 139, 347-360.

38. Pichlak, M. (2012). Uwarunkowania innowacyjności organizacji. Studium teoretyczne $i$ wyniki badań empirycznych. Warszawa: Difin.

39. Polska Agencja Rozwoju Przedsiębiorczości (PARP) (2008). Potencjał matych i średnich przedsiębiorstw $w$ dziedzinie kreowania nowych produktów innowacyjnych - rozwiąania proekologiczne. Warszawa.

40. Polska Agencja Rozwoju Przedsiębiorczości (PARP) (2015). Potencjat innowacyjności $w$ przedsiębiorstwach $i$ otoczeniu społeczno-gospodarczym. Dobre przykłady, słabości, perspektywy na przyszłość. Warszawa.

41. Poznańska, K. (1998). Uwarunkowania innowacji w matych i średnich przedsiębiorstwach. Warszawa: Dom Wydawniczy ABC.

42. PRT Implementation Model 2015 [Model wdrażania Programu Rozwoju Technologii Województwa Śląskiego na lata 2010-2020]. Katowice: Marshal's Office of the Silesian Voivodeship.

43. Przychodzeń, J. (2019). Ekoinnowacje w przedsiębiorstwie. Zarządzanie, pomiar i wpływ na wyniki finansowe. Warszawa: CeDeWu.

44. Rave, T., Goetzke, F., \& Larch, M. (2011). The Determinants of Environmental Innovations and Patenting: Germany Reconsidered. Ifo Working Paper, 97.

45. Reid, A., \& Miedzinski, M. (2008). Eco-innovation. Final Report for Sectoral Innovation Watch. Systematic Eco-Innovation Report, Technopolis Group, 1-3.

46. Rennings, K. (1998). Towards a Theory and Policy of Eco-Innovation - Neoclassical and (Co-)Evolutionary Perspectives. Centre for European Economic Research (ZEW), Discussion Paper, No. 98-24. 
47. Rennings, K. (2000). Redefining innovation - eco-innovation research and the contribution from ecological economics. Ecological Economics, 32, 319-332.

48. Rennings, K., \& Zwick, T. (2002). The employment impact of cleaner production on the firm level - empirical evidence from a survey in five European countries. International Journal of Innovation Management (IJIM), Special Issue on "The Management of Innovation for Environmental Sustain-ability”, 6(3), 319-342.

49. Wagner, M. (2008). Empirical influence of environmental management on innovation: evidence from Europe. Ecological Economics, 66(2-3), 392-402.

50. Wagner, M. (2009). Innovation and Competitive Advantages from the Integration of Strategic Aspects with Social and Environmental Management in European Firms. Business Strategy and the Environment, vol. 18(5), 91-306.

51. Woźniak, L., \& Woźniak, G. (2021). Eco-innovations as a factor of sustainable development of agriculture and food processing. Problems of Agricultural Economics, 1(366), 74-90, DOI: 10.30858/zer/132396.

52. Zarębska, J., \& Michalska, M. (2016). Ecological innovations as a chance for sustainable development - directions and obstacles in their implementation. Management, Vol. 20, No. 2, 49-64, DOI:10.1515/manment-2015-0050.

53. Zuzek, D. (2015). Determinants of the development eco-innovation in the SME sector for example in Malopolska province. Roczniki Naukowe Stowarzyszenia Ekonomistów Rolnictwa i Agrobiznesu, 17, 1, 240-244. 